\title{
Effect of Fe-EDTA on the Development of Isolated Ovules of Petunia hybrida
}

\author{
Yoshiji Niımi \\ Faculty of Agriculture, Niigata University, Niigata
}

\begin{abstract}
Summary
The present investigation dealt with in vitro the growth of the excised ovules just after fertilization in Petunia hybrida.

Most of these ovules were cultured on a medium composed of inorganic salts, vitamins, glycine, sucrose and agar without any growth regulators or plant extracts. They were able to develop into viable seeds only when cultured on the medium containing Fe-EDTA as an iron source. Some of the seeds germinated in situ immediately and developed until flowering. However, ovules cultured on a medium containing ferric citrate failed to develop into viable seeds.

The addition of some growth regulators to the medium containing Fe-EDTA rather inhibited the normal development of ovules. A supply of casamino acids did not also increase the percentage of normal seedlings; however, the number of normal seedlings increased progressively with decreasing the concentration of sucrose.
\end{abstract}

\section{Introduction}

After the first success in Papaver somniferum(11), the aseptic culture of very young ovules after fertilization have been made by many workers for various species $(1,3,13,16)$. When separated from placental tissue, however, the young ovules containing a zygote or 2-celled proembryo could not develop into mature seeds except in Zephyranthes (8) and Trifolium(13). On the other hand, viable seeds were easily obtained in the culture of entire ovaries $(1,3)$. Guha and Johri(3) suggested from these results that placental tissue and ovary wall may supply some unknown metabolites which are essential for the early growth of fertilized ovules.

It was shown in previous papers $(14,15)$ that in Petunia hybrida fertilized ovules attached to the placenta, 3 days after pollination, are able to devlop easily into viable seeds on a modified Nitsch's medium. Furthermore, the experimental results suggested that an addition. of nitrogen of ammonium form and the relatively high concentration of boric acid, iron and sucrose to the Nitsch's medium (1951) are very important for the full development of ovules. The present experiment was carried

\footnotetext{
Keceived for publication July 30, 1973.
}

out to determine whether the very young ovules, which were isolated from placentaI tissue immediately after fertilization, can develop into viable seeds on the similar medium.

\section{Materials and Methods}

The two self-incompatible clones of Petunia hybrida, W $166 \mathrm{H}$ (incompatibility alleles $\mathrm{S}_{2}$, $\left.\mathrm{S}_{3}\right)$ and $\mathrm{K} 146 \mathrm{BH}\left(\mathrm{S}_{6}, \mathrm{~S}_{6}\right)$, which were originally established by Straub (1946), were chosen for the present experiment.

Plants were grown in a phytotoron at $23 \pm$ $1^{\circ} \mathrm{C}$. Flower buds of clone $\mathrm{W} 166 \mathrm{H}$ were emasculated and bagged one day before an-

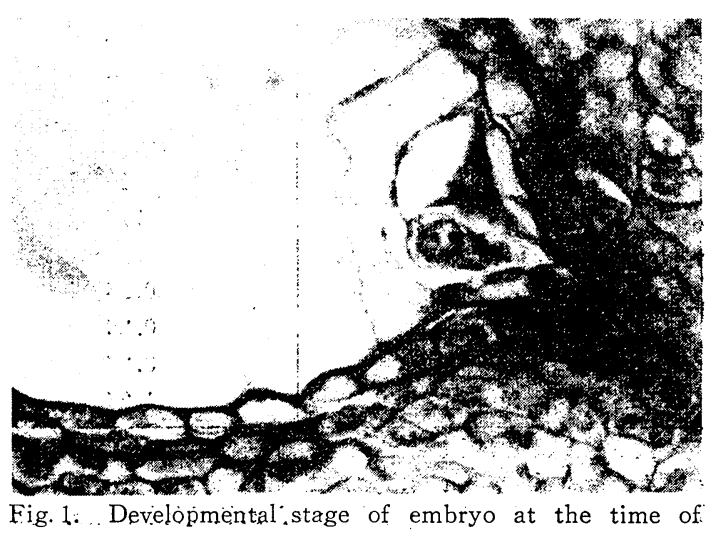
inoculation' ( 3 days after pollination). $\times 100$. 
thesis. The day at anthesis, they were pollinated with fresh pollen grains of $\mathrm{K} 146 \mathrm{BH}$. The ovules, 3 days after pollination, were used for culture. The developmental stage of embryo at the time of inoculation is shown in Fig. 1.

The procedures of ovule culture were as follows. The ovary 3 days after pollination was excised and surface-sterilized by dipping them in a $70 \%$ ethanol, immersing for 10 minutes in a $10 \%$ fresh chlorine water, and finally washing twice with sterile distilled water. Subsequently, the ovary wall was peeled and the placental tissues thus exposed were scraped gently to isolate ovules. The 200 400 isolated ovules per flask were cultured on $20 \mathrm{~m} l$ of agar nutrient medium in $50 \mathrm{ml}$ Erlenmeyer flasks.

The nutrient medium containing Fe-ethylenediaminetetraacetic acid as an iron source (designated as Fe-EDTA medium in the text) was prepared upon the basis of preceding results (15) obtained from the culture of ovules attached to the placenta (Table 1). Unless otherwise described, $7.5 \%$ sucrose and $0.5 \%$ agar were incorporated into the medium. The

Table 1. Compostion of the Fe-EDTA medium for cultures of isolated ovules containing a zygote in Petunia hybrida.

\begin{tabular}{|c|c|c|}
\hline \multirow[t]{6}{*}{ a) } & Major elements & $\mathrm{mg} / \mathrm{l}$ \\
\hline & $\mathrm{KNO}_{3}$ & 625 \\
\hline & $\mathrm{Ca}\left(\mathrm{NO}_{3}\right)_{2} \cdot 4 \mathrm{H}_{2} \mathrm{O}$ & 500 \\
\hline & $\mathrm{NH}_{4} \mathrm{NO}_{3}$ & 80 \\
\hline & $\mathrm{KH}_{2} \mathrm{PO}_{4}$ & 125 \\
\hline & $\mathrm{MgSO}_{4} \cdot 7 \mathrm{H}_{2} \mathrm{O}$ & 125 \\
\hline \multirow[t]{6}{*}{ b) } & Minor elements & $\mathrm{mg} / \mathrm{l}$ \\
\hline & $\mathrm{H}_{3} \mathrm{BO}_{3}$ & 25 \\
\hline & $\mathrm{ZnSO}_{4} \cdot 7 \mathrm{H}_{2} \mathrm{O}$ & 0.5 \\
\hline & $\mathrm{MnSO}_{4} \cdot 4 \sim 6 \mathrm{H}_{2} \mathrm{O}$ & 3 \\
\hline & $\mathrm{CuSO}_{4} \cdot 5 \mathrm{H}_{2} \mathrm{O}$ & 0.025 \\
\hline & $\mathrm{Na}_{2} \mathrm{MoO}_{4} \cdot 2 \mathrm{H}_{2} \mathrm{O}$ & 0.025 \\
\hline c) & Fe-EDTA* & $10 \mathrm{ml} / l$ \\
\hline d) & Glycine & $7.5 \mathrm{mg} / \mathrm{l}$ \\
\hline \multirow[t]{5}{*}{ e) } & A mixture of vitamins & $\mathrm{mg} / l$ \\
\hline & Calcium pantothenate & 0.25 \\
\hline & Pyridoxine-HCl & 0.25 \\
\hline & Thiamine- $\mathrm{HCl}$ & 0.25 \\
\hline & Nicotinic acid & 1.25 \\
\hline
\end{tabular}

* A stock solution containing 5 grams $\mathrm{FeSO}_{4} \cdot 7 \mathrm{H}_{2} \mathrm{O}$ and 4 grams disodium ethylenediaminetetraacetate, dihy. drate $\left(\mathrm{Na}_{2}\right.$-EDTA) per liter of redistilled water. 10 $\mathrm{m} l / l \mathrm{Fe} \cdot \mathrm{EDTA}$ corresponds to $10 \mathrm{mg} / l$ iron
$\mathrm{pH}$ of the Fe-EDTA medium was adjusted to 5.7 using $0.1 \mathrm{~N} \mathrm{NaOH}$ and $0.1 \mathrm{~N} \mathrm{HCl}$ before autoclavaing. A medium containing $40 \mathrm{mg} / \mathrm{l}$ ferric citrate instead of Fe-EDTA (designated as ferric citrate medium in the text) was also used and adjusted to $\mathrm{pH}$ 4.5. Difco Bacto vitamin-free casamino acids and growth regulators such as indole-3-acetic acid (IAA), gibberellic acid $\left(\mathrm{GA}_{3}\right)$ and kinetin were in some instances added to the Fe-EDTA medium.

All cultures were maintained in the room at about $25^{\circ} \mathrm{C}$. Some cultures were used for embryonic studies and the sectioned preparations were stained by Delafield's hematoxylin.

\section{Results}

Development of ovules in vitro under the presence or absence of $\mathrm{Fe}$-EDTA.

After 27 days of culture on the Fe-EDTA medium, a well-developed embryo with normal cotyledons, massive endosperm tissue and testa were observed (Fig. $2 \mathrm{~A}$ ). At the 30 50th day some of them germinated in situ without

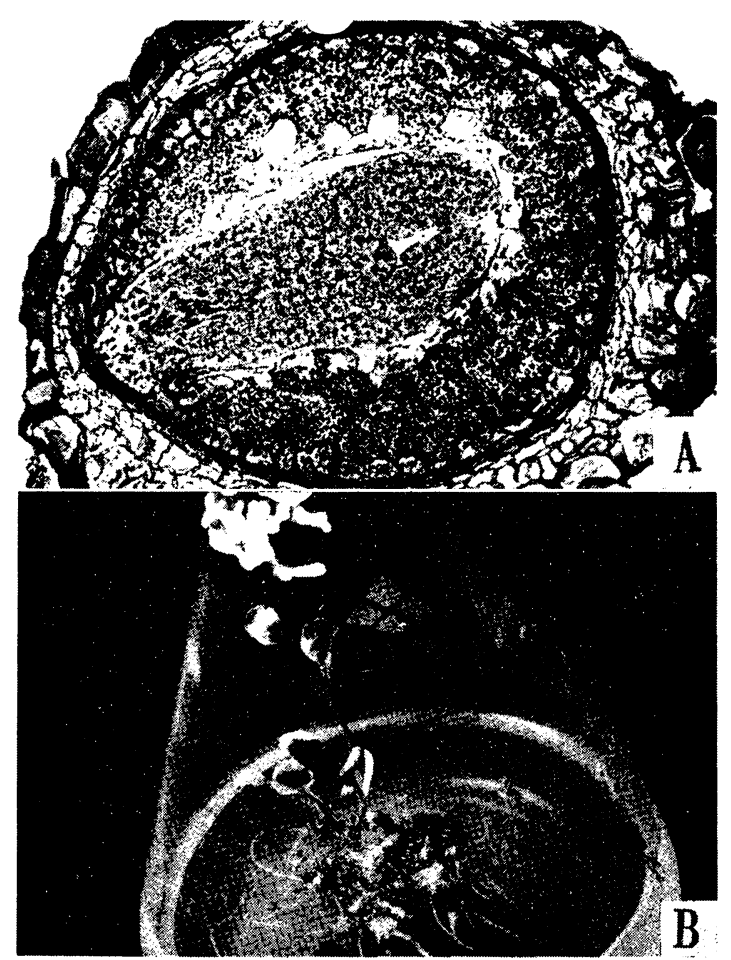

Fig. 2. Growth of excised ovules on the Fe-EDTA medium. A, 27 days-old embryo and endosperm. $\times 100$. B, seedlings formed in situ in the 40 th day. 

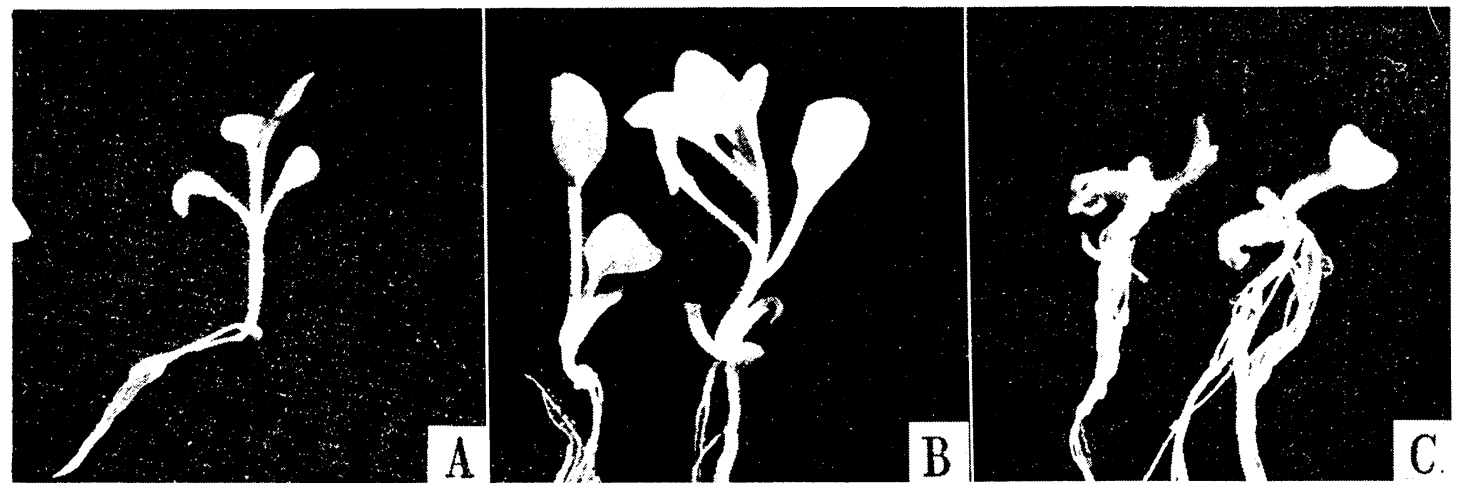

Fig. 3. Seven weeks old seedings obtained through isolated ovules on the Fe-EDTA medium. (A) normal seedling with two cotyledons and roots. (B) seedling with one cotyledon and roots at the germination stage. Later it differentiated leaves and developed into normal mature plant. (C) a callus-like mass with leaves and roots.

undergoing dormancy (Fig. $2 \mathrm{~B}$ ). Seedlings from this medium could be classified into three different types (Fig. 3) ; (i) normal seedling with two cotyledons and roots (designated as type-A. Fig. $3 \mathrm{~A}$ ), (ii) slightly malformed seedling with only one cotyledon and roots, which eventually differetiates normal shoot (designated as type-B. Fig. 3 B) and (iii) a callus-like mass with leaves and roots, which fails to develop into normal seedling (type-C. Fig. 3C).

In the ferric citrate medium the seeds did not germinate at all. After 27 days the embryo reached to the globular stage, but further development did not proceed normally (Fig. $4 \mathrm{~A}$ ). Even after 47 days almost all the embryos still remained in the globular shape, although the size of seed became to be comparable to that of seed on the $\mathrm{Fe}^{-}$ EDTA medium (Fig. 4 B).

These findings indicate evidently that $\mathrm{Fe}^{-}$ EDTA is effective for the development of ovules excised soon after fertilization and stimulates strongly the development of inner embryo.

Influence of decreased level of sucrose on seedling development.

The preceding experiments showed that $\mathrm{Fe}-$ EDTA was essential for the development of ovules in vitro. However, the development of cotyledon retarded frequently (type-B and $-C)$. The experiment was carried out to investigate whether the concentrations of sucrose was influenced on the differentiation of embryo, especially the development of cotyledons.

Fig. 5 shows the influence of sucrose concentrations on the development of cotyledons and roots. With $6.5 \%$ sucrose the number of type-A seedlings increased slightly as compared with those obtained on the media containing 7.0 or $7.5 \%$ sucrose. Although many mature seeds were formed even in the

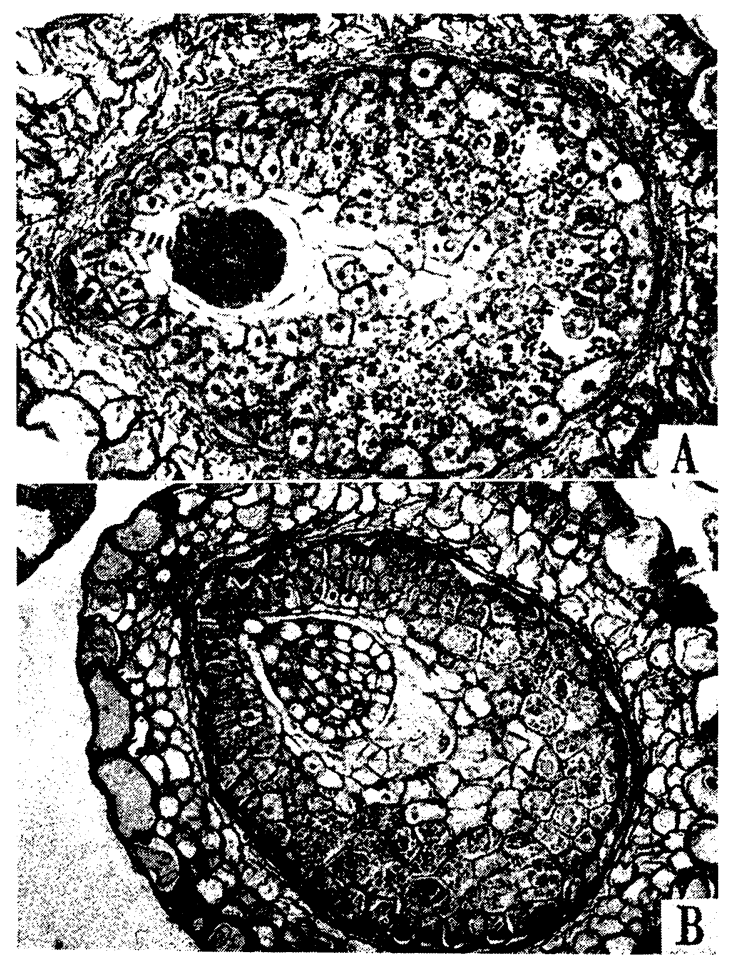

Fig. 4. Growth of excised ovules on tne ferric citrate medium. A, 27 days-old after culture. B, 47 daysods. $\times 100$. 


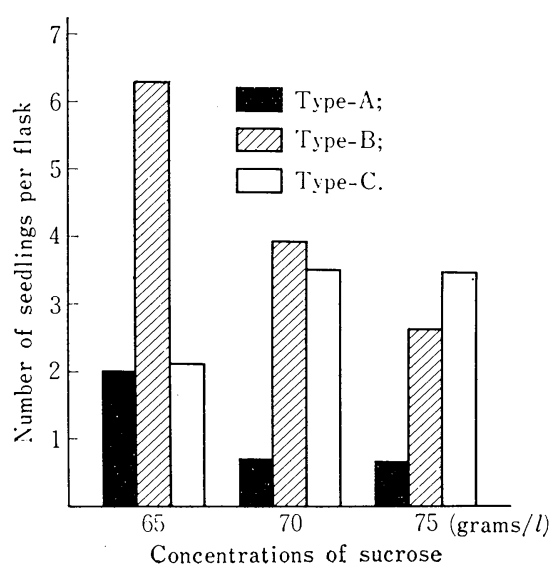

Fig. 5. Influence of sucrose concentrations.

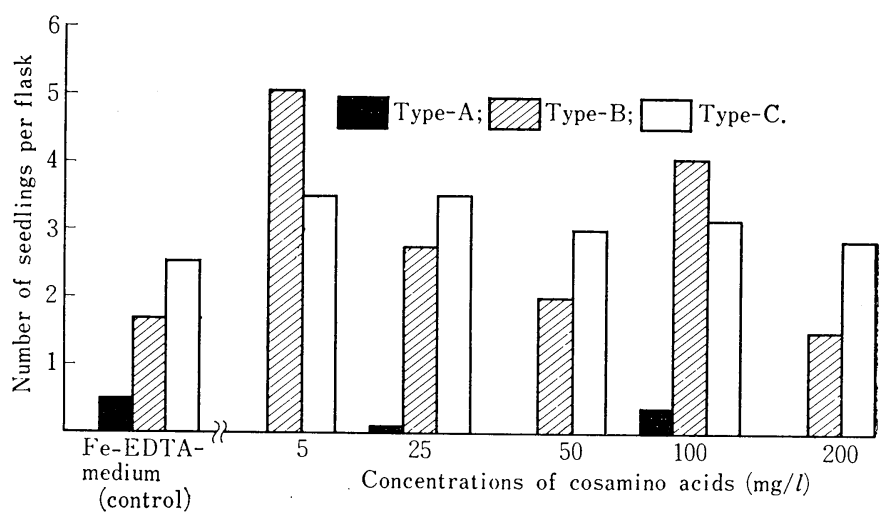

Fig. 6. Influence of varying concentrations of casamino acids on the production of seedlings.
7.0 and $7.5 \%$ sucrose media, which could eventually germinate, the development of cotyledons was considerably poor. As a result, the number of type-A decreased and the seedlings of type- $\mathrm{B}$ and $-\mathrm{C}$ increased.

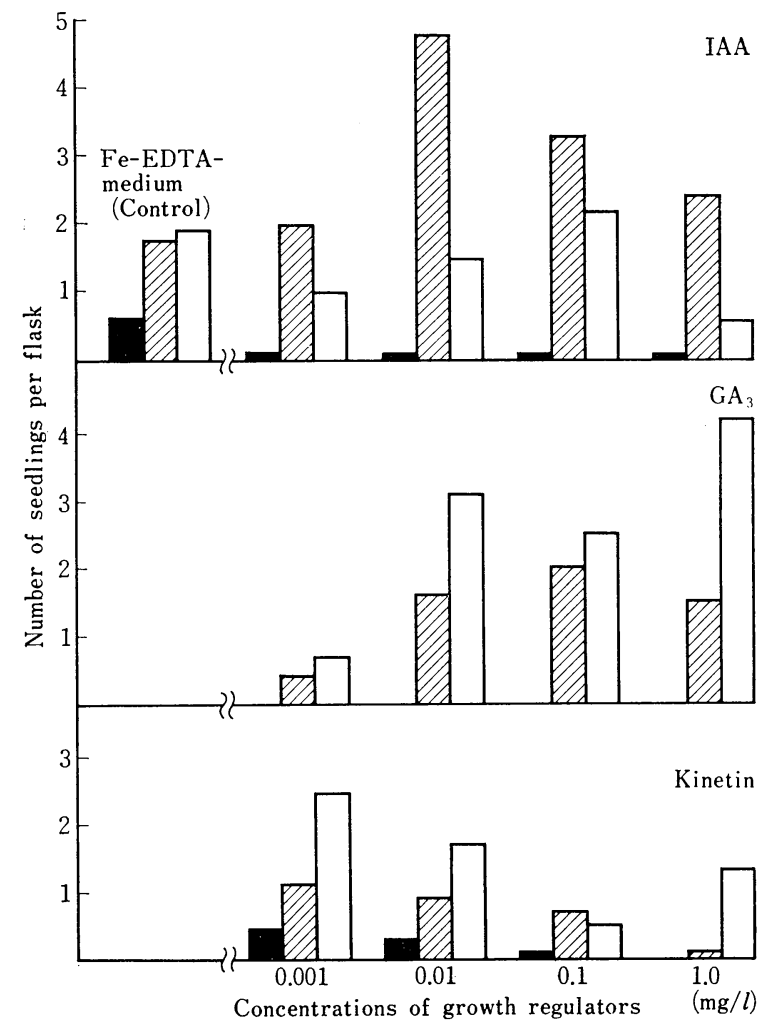

Type-A; ZII Type-B; $\square$ Type-C.

Fig. 7. Influence of IAA, $\mathrm{GA}_{3}$ and kinetin.added singly to the Fe-EDTA medium on the production of seedli

\section{Influence of the concentration of casamino} acids.

When the excised ovules were cultured on the Fe-EDTA medium supplemented with various concentration of casamino acids, any increase in number of type-A seedlings was not seen (Fig. 6). On the other hand, the rate of the appearance of the type- $B$ was much higher than that on the control medium. It seems from these results that an addition of casamino acids to the $\mathrm{Fe}^{-}$ EDTA medium is ineffective for the normal differentiation of embryo, especially for the development of cotyledon.

Influence of some growth regulators.

The number of the type- $B$ seedlings increased when IAA was added to the Fe-EDTA medium, as shown in Fig. 7. After 30 days of culture the seeds contained a large embryo but not endosperm (Fig. $8 \mathrm{~A}$ ). The length of cotyledons were shorter than that on the Fe-EDTA medium.

An increase in number of type- $A$ and $-B$ seedlings wils not obtained by $\mathrm{GA}_{3}$. On the contrary, the type-C seedlings increased as the concentrations of $\mathrm{GA}_{3}$ increased. 0.001 $\mathrm{mg} / l \quad \mathrm{GA}_{3}$, inhibited strongly the development of embryo and endosperm (Fig. $8 \mathrm{~B}$ ).

Fig. 7 also shows the frequency of seedling formation under various concentrations of kinetin $(0.001,0.01,0.1$ and $1.0 \mathrm{mg} / l)$. After 30 days of culture on $0.001 \mathrm{mg} / l$ kinetin an abnormal embryo and a massive endosperm were seen (Fig. 8C). The number of type-A and $-\mathrm{B}$ seedlings decreased with 


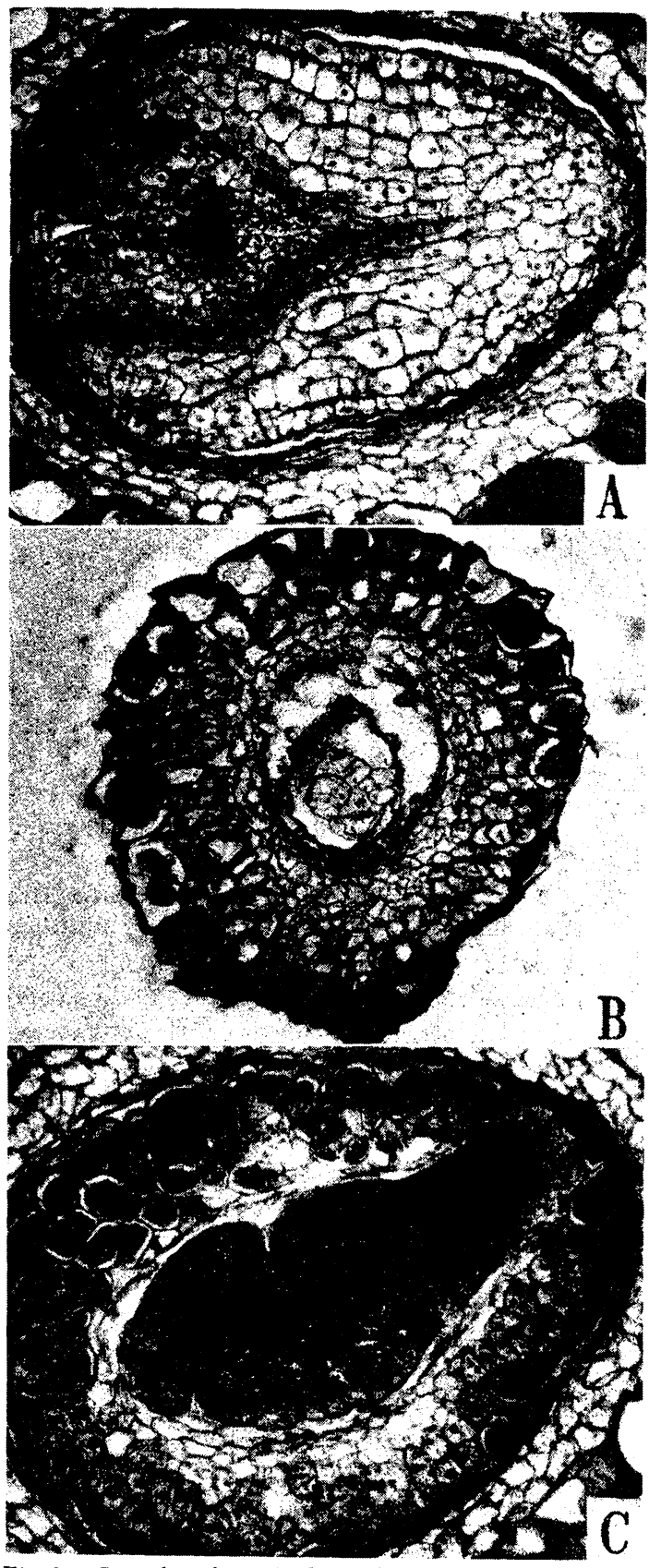

Fig. 8. Growth of excised ovules on the Fe-EDTA medium supplemented with growth regulators, IAA, $\mathrm{GA}_{3}$ or kinetin. $\mathrm{A}, \mathrm{B}$ and $\mathrm{C}$ : embryos and endosperms from the $F e$-EDTA medium plus $0.001 \mathrm{mg} / l$ IAA (A), $0.001 \mathrm{mg} / l \mathrm{GA}_{3}(\mathrm{~B})$ and $0.001 \mathrm{mg} / l$ kinetin (C), respectively, 30 days after culture. $\times 100$.

increasing the concentrations of kinetin.

\section{Discussion}

The present investigation clearly showed that ovules containing the zygote separated from the placenta can develop into the viable seeds. They germinated in situ on the medium composed of inorganic salts, Fe-EDTA, vitamins, glycine, sucrose and agar without any growth regulators or plant extracts. When cultured on a medium containing ferric citrate as an iron source, however, they failed to develop into mature seeds.

Extensive works on ovule and ovary cultures have been made by the use of Nitsch's (1951) inorganic and vitamins solution supplemented with growth regulators, casamino acids and/or plant extracts $(3,8,11,12,13)$. The standard Nitsch's medium contains $10 \mathrm{mg} / l$ ferric citrate as an iron source. As growth proceeds in plant tissue culture, the $\mathrm{pH}$ drifts towards neutrality (6) and alteration in $\mathrm{pH}$ toward neutrality would result in the limited availability of the iron and the other metal ions(7). Street(16) found that the value of $\mathrm{pH}$ at which a low concentration of iron citrate or tartrate becomes unavailable is about 6.0. As the ferric citrate medium used in the present investigation is adjusted to $\mathrm{pH} 4.5$ and also contains a high concentration of about $8 \mathrm{mg} / \mathrm{l}$ iron, the availability of $\mathrm{Fe}$ to the isolated ovules may be left out of consideration.

The results described above lead to a consideration of the mechanism by which chelating agent such as EDTA influence the development of embryo. This may undoubtedly be the most important question raised by the present study. Although several reports have been presented about the action of chelating agents on the growth of intact plant, there is no report about the effect of EDTA on the growth of embryo and endosperm in ovule culture. Heath and $C_{\text {Lark }}(4,5)$ reported the chelating agents such as EDTA or 8-hydroxyquinoline were, in fact, auxins as operationally defined. They observed that EDTA, like indole-3-acetic acid, suppressed the elongation of wheat roots. Burström and Tullin (2) found, as reported by Heath and CLARK (4), the EDTA suppressed root growth. This suppression, however, was due to a deficiency in cell multiplication, whereas auxin suppressed only cell elongation. On the other hand, Thimann and Takahashi(18) have indicated that the effect of EDTA and auxin are clearly 
different. KLEIN and MANos(9) also reported that Fe-EDTA increased the growth of crown gall tissue of both Parthenocissus and Helianthus, but its effect is not that of an auxin. They found that these tissue cultures are protrophic for auxins and are, in fact, inhibited by these growth regulators. КосHCHAR et al (10) reported that inclusion of chelated metal ions to the nutrient medium influences the differentiation of a callus of Nicotiana tabacum in culture. They observed that vegetative buds could be induced on the callus obtained from the haploid plant by the chelating agents and pointed out that chelating agents, besides stimulating growth, might also regulate morphogenesis. Furthermore, they emphasized that the differential effects of the chelating agents indicate the involvement of some specific action of the chelated metal ions which might activate some specific enzyme system involved in organogenesis.

In Petunia, the presence of Fe-EDTA is essential for the development of ovules containing a zygote, although Fe-EDTA does not always function as a substitute of the placental tissue. SAchAR and $\mathrm{K}_{\mathrm{APOOR}}(16)$ reported that the addition of IAA, GA, 2,4-D, IBA and kinetin to the Nitsch's medium (1951) fails to induce growth of Zephyranthes if isolated prior to the formation of globular stage. Moreover, these substances inhibit the development of endosperm. The results reported by other workers $(1,3,12,13)$ are in general agreement with those of SACHAR and $\mathrm{K}_{\mathrm{APOOR}}(16)$. In the present investigation, when excised at zygote stage and cultured on the Fe-EDTA medium, the ovules grew up to the mature seeds which germinated in situ, but when some growth regulators were added to the Fe-EDTA medium the normal development of embryo and endosperm was inhibited. Further, any viable seed was not formed even when IAA was added to a medium containing ferric citrate as an iron source (unpublished). Thus, it is supposed that Fe-EDTA plays a role different from growth regulators for the development of ovules.

On the basis of these observations and other results(15), we are inclined to think that some of the positive effect of Fe-EDTA on the development of isolated ovules may be due to both the buffering of iron by EDTA and the complexing of EDTA and other metals, for example, in some specific enzyme system. Further, without evidence, we presumed that the placental tissue supplies some substances which are essential for the normal development of ovules; besides, it also plays some important roles in the regulation of utilization of nutrient elements including growth substances which are produced by itself and the developing ovules.

\section{Acknowledgement}

The author is grateful to Prof. Y. Kato of the University of Fukui for a critical reading of the manuscript.

\section{Literature cited}

1. DulieU, H. L. 1966. Pollination of excised ovaries and culture of ovules of Nicotiana tabacum L. Phytomorpho. $16: 69-75$.

2. BURSTRÖM, H., and V. TULliN. 1957. Observation on chelates and root growth. Physiol. Plant. $10: 406-417$.

3. GUHA, S., and B. M. JOHRI. 1966. In vitro development of ovary and ovules of Allium cepa L. Phytomorpho. $16: 354-363$.

4. Heath, O. V.S. and J. E. CLARK. 1956. Chelating agents as plant growth substances. Nature 177 : 1118-1121.

5. - . 1956. and Chelating agents as growth substances. Ibid. $178: 600$ 601.

6. Hitdebrandt, A. C., A. J. Riker., and B. M. DUGGaR. 1945. Growth in vitro of excised tobacco and sunflower tissue with different temperatures; hyhrogen-ion concentrations and amounts of sugar. Amer. J. Bot. 32 ; 357 -361 .

7. —. influence of the composition of the medium on growth in vitro of excised tobacco and sunflower tissue cultures. Ibid. $33: 591-597$.

8. KAPOOR, M., 1959. Influence of growth substances on the ovules of Zephyranthes. Phytomoropho. $9: 313-315$.

9. KLEIN, R. M. and G. E. MANOS. 1960. Use of metal chelates for plant tissue cultures. Annals New York Acad. Sci. $88: 416-425$.

10. KOCHChaR, T. S., P. R. Bhalla., and P. S. SABHAWAL. 1971. In vitro induction of vegetative buds in tobacco callus by chelating agents. Can. J. Bot. 49 : 391-394.

11. MAHESHWARI, N. 1958. In vitro culture of 
excised ovules of Papaver somniferum. Science $127: 342$.

12. - and M. LAL. 1961. In vitro culture of excised ovules of Papaver somniferum. Phytomorpho. $11: 307-314$.

13. NAKAJIMA, T., Y. DOYAMA, and H. MATSUMOTO. 1969. In vitro culture of excised ovules of white clover, Trifolium repense $\mathrm{L}$. Japan J. Breeding $19: 373-378$.

14. NiIMI, Y. 1971. Effects of concentration of inorganic nitrogen, $\mathrm{KNO}_{3}$ and/or $\mathrm{NH}_{4} \mathrm{NO}_{3}$ on embryo in vitro in Petunia hybrida. J. Japanese Soc. Hor. Sci. $40: 56-63$.
15. 1973. Influence of iron, boron and sugars on viable seed production in excised ovule culture in Petunia hybrida. Ibid. 42 : 163-169.

16. SACHAR, R. C., and M. KAPOOR. 1959. In vitro culture of ovules of Zephyranthes. Phytomorpho. $9: 147-156$.

17. Street, H. E. 1957. Nutrition and metabolism of plant tissue culture. J. Natl. Cancer Inst. $19: 467-494$.

18. THIMANN, K. V., and N. TAKAHASHI. 1958. The action of chelating agents on growth of Avena. Plant physiolgy 33 : supple. 33.

Petunia hybrida のはい珠培養にお打る Fe-EDTA の効果

$$
\text { 新 } \underset{\text { (新潟大学農学部) }}{\text { 芳 }}
$$

摘

受精後まもない接合子をもつたはい柇を胎座から切り 離し培養したところ, 植物生長調節物質や植物抽出物を 全く含まない無機塩やビタミン類を中心とする完全合成 培地で多くの健全な実生を得ることができた。

若いはい珠を完熟種子に育て，健全な実生を得ること ができるかどらかは，培地に添加する鉄の種類によつて 大きく左右されることが明らかとなつた.すなわら， $\mathrm{Fe}-\mathrm{EDTA}$ (Fe として $10 \mathrm{mg} / \mathrm{l}$ ) を含有する培地では多 くの実生が得られた。 しかし Fe-EDATのかわりにクエ ン酸第二鉄を添加した培地からは灭生は全く得られなか

\section{要}

つたＦr-EDTA を含む培地から得られる䒠生には，形 態のうえから扣扣よそ三種類あり，健全な突生とともに 子葉が十分に分化していない奇形の実生があつた.

以上の結果に基づき, しょ糖の濃度, 植物生長調節物 質およびカザミノ酸がはい珠の発達，とくにはいの分化 に影響するかどらかを Fe-EDTAを含む培地を用いて検 討した。しよ糖濃度を $7.5 \%$ から $6.5 \%$ に減らすと健全 な突生数が増加した。 しかし植物生長調節物質やカザミ ノ酸の添加ははい珠の正常な発達に効果がなかつた。 